\title{
POSSIBILITIES OF CONNECTING A SEA PORT WITH DRY PORTS IN THE HINTERLAND IN ORDER TO ATTRACT REGIONAL CARGO: CASE STUDY - PORT OF BAR
}

\author{
Dalibor Pelević ${ }^{1}$ \\ ${ }^{1}$ MSC Montenegro d.o.o., Obala 13. jula 6, Bar, Montenegro \\ Received 15 November 2020; accepted 27 January 2021
}

\begin{abstract}
This paper presented the benefits of a seaport in intermodal transport which is connected by railway with dry ports in the region of Western Balkans in order to increase its competitiveness. Port of Bar is considered as a case study. The aim of this paper was to confirm the hypothesis that a seaport connected to its hinterland by regular container trains has a competitive position, lower intermodal transport costs than a port connected to its hinterland by truck transport only. The special attention was given to the Serbian market, the main hinterland of Bar port. The comparative analysis of intermodal transport between the Port of Bar and the main economic centers in Serbia, confirmed the hypothesis. The use of rail transport for transport of containers is a prerequisite for increasing competitiveness of a seaport.
\end{abstract}

Keywords: dry ports, intermodal transport, competitiveness, Bar port.

\section{Introduction}

This paper aims to simulate the possibilities offered by shifting of intermodal transport from road to railway, with reference to the Port of Bar and its hinterland. The results obtained by analyzing all costs that exist by using truck transport compared to railway, from the port of Bar to the ten largest economic centers in Serbia. Maritime transport is the most important, cheapest and most economical mode of transport. From an economic point of view, the advantages of maritime transport are: large individual ship capacities, huge total capacity of this type of transport, low cost of transport route by sea compared to the same route by other modes of transport, flexible demand, long service life and sea as a wide and free road that does not require large investments in infrastructure (Naletina and Perkov, 2017). In total world trade, around $90 \%$ of all goods are transported overseas, while $19 \%$ of the total amount is transported by containers. The percentage of goods transported by containers is growing faster than transport of goods in liquid, bulk form and transport of general cargo. Although it makes less than $1 / 5$ in the total overseas transport observing the quantity of transported goods in tons, about $60 \%$ of the total value of transported goods by sea use intermodal transport (Unctad, 2019). There are 927 seaports in the world that are involved in the liner container shipping by global shipping companies (UnctadSTAT, 2020) such as Maersk,

${ }^{1}$ Corresponding author: dalibor.pelevic@msc.com 
MSC, COSCO, CMA CGM, Hapag Lloyd and others or smaller container shipping companies that do their business focused on a specific region. All seaports are struggling to serve as many containers as possible and thus make as much profit as possible through transshipment manipulations. Most of them, whether larger or smaller, which are best connected to world or those that are less connected, compete each other for same hinterland. One of ways for a seaport to be more competitive is to use the principle of economies of scale. The ongoing use of economies of scale in container transport can be seen as revolutionary as the gradual reduction in transport costs achieved through its use (Rodrigue and Notteboom, 2009). Two ways to achieve cost reduction are the use of container trains or the transport of containers by inland waterways. This paper will consider the benefit of introducing a regular container train from the port of Bar, which now uses truck transport only. In addition to the benefits reflected in cost reduction, rail transport is also an EU priority. Namely according to the EU transport strategy until 2050 (European Commission, 2011), over $50 \%$ of freight traffic should be shifted from road to rail on routes of over $300 \mathrm{~km}$. In addition to the benefits in order to protect the environment, the EU has set itself that goal to decrease its depend on import of fuels.

\section{Literature Review}

One way of increasing the hinterland means to use trains and barges rather than trucks. Compared to road, both rail and inland waterways come with advantages such as lower environmental strain, lower nuisance in port city traffic, lower transport distance costs, faster flow throughput in ports and, in most cases, less sensitiveness to delays by traffic congestion (Roso et al., 2009). The advantages are distributed among most actor categories and each of them can find reason for advocating the use of alternatives to road for hinterland transport. The latter two advantages appeal to truckers since they are rarely compensated for standing in lines at ports' gates and in congested traffic. Notable disadvantages are costs and lead times over short distances and rail congestion close to the ports (Woxenius and Bergqvist, 2008). One of the main advantage of rail and inland waterway transport is less damage caused by traffic accidents compared to road transport, as well as the victims that these accidents bring with them. The notion of dry ports within the transport network has been developed, inter alia, to be a support to seaports and the sustainable development of international transport (Roso, 2013). The increase in the transport of goods by sea generates an almost proportional increase in the land flow of goods and what happens on land will affect the ability of the intermodal transport system to further accept the growth of international trade. This goal can be achieved by dry ports, which have been developed to support maritime operations and also overall intermodal system operations (Bask et al., 2014). The concept of a dry port is based on the fact that it is connected to the seaport by rail. (Roso et al., 2009) lists 3 types of dry ports: close, midrange and distant. The one of key element for efficient operations of intermodal terminals of a transport network with a certain number of seaports is the high quality of dry ports in its hinterland (Mlinarić et al., 2011). The rail transport uses 6 times less energy than road transport and has 9 times less carbon dioxide 
emissions (Port of Antwerp, 2020). A big problem in countries outside the EU zone represents large truck delays at the borders, which leads to extremely high transport costs. The poor road infrastructure causes the difficult working conditions of drivers themselves, which all affects their outflow in the EU and the USA. The use of economies of scale in connecting the seaport with its hinterland is one of the basic means in achieving the competitiveness of one direction in intermodal transportation. According to (Port of Antwerp, 2020) the using of rail transport was $8 \%$ of the total number of transshipped containers in 2019, while the barge transported $36 \%$ of the total transshipped containers, which is combined $44 \%$ of the total container transshipment in the port of Antwerp. (Port of Hamburg, 2020) states that the port is connected to its hinterland with 300 container trains a day and about 30 barges. The port of Hamburg had an annual transshipment of around 8.7 million TEU (2019), of which 3.4 million TEU are transshipped to other destinations in the port itself or almost $40 \%$, the remaining of 5.4 million TEU went to hinterland. Out of that number, $44 \%$ is transported by rail, $54 \%$ by truck while $2 \%$ is transported by inland waterways. It is interesting that over $90 \%$ of cargo intended for countries outside Germany is transported by rail. The situation is similar in other developed European and world ports. Shipping line COSCO bought the majority stakes in the largest Greek port of Piraeus in 2009, whose turnover in the next 9 years increased by $700 \%$ and reached 4.9 million TEU in 2018. (COSCO Shipping Greece, 2020) states that in 2017 was launched intermodal service which connects the port of Piraeus with Bulgaria and North
Macedonia where trains travel 1 day, Serbia and Romania 2 days, the Czech Republic, Austria, Slovakia and Hungary 3-4 days and Poland where train travel 5-6 days. The number of trains in 2019 reached 10 per week and constantly growing in accordance with the possibilities of the route, in which the Chinese invest the significant financial resources together with the countries of the region. The bottlenecks on the route in North Macedonia and Central Serbia are the chance for the logistical route through the port of Bar, which will be discussed later in the paper.

\section{The Research Problem}

The main precondition of benefits that comes with the principle of economies of scale is existence of dry ports. In the case of container transport by inland waterways, there are ports located on the river which are connected with 3 modes of transport, i.e. by river, by rail and by road. The connecting the port of Bar with dry ports in hinterland with regular container trains is considered in this paper. The establishment of dry ports entails the need to develop rail transport from the seaport to its hinterland. The main role is played by remote dry ports. They allow seaport to reach a hinterland that a seaport could not count on before. If we consider the port of Bar, an example of a long range dry port could be the dry port in Budapest (Bilk terminal). These are dry ports located at a distance of over $800 \mathrm{~km}$ from the seaport (Roso et al., 2009). The figure 1 shows the potential connection of the port of Bar with dry ports of medium and long range in the region, which would attract regional cargo to the logistics route via Montenegro, i.e. the port of Bar. 


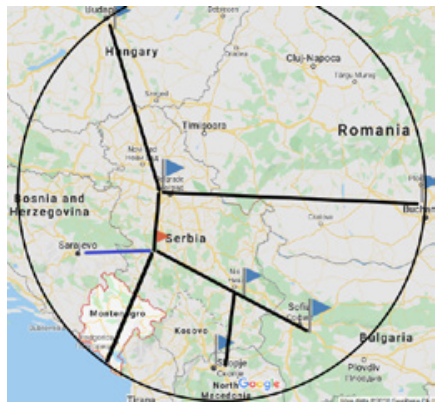

Fig. 1.

Example of Potential Connection of the Port of Bar with Dry Ports of Long and Medium Range in the Region Source: Author

An example of a medium-distance dry port for the case of the port of Bar could be the dry ports in Belgrade. They are dry ports up to $500 \mathrm{~km}$ from a sea port. It is a port located in an area that is served by trucks, but due to the significant amount of cargo, in order to relieve the road, it would be useful for the goods from that seaport to go by rail (Roso et al., 2009). In the case when there are several seaports in a small region, which have a common hinterland, the use of a dry medium-range port brings a competitive advantage to seaport. A good example is the area of the Western Balkans and the competition of the ports of Rijeka, Bar and Thessaloniki for the Serbian market, where the port of Rijeka serves the highest percentage of Serbian cargo because of connection to dry ports in Belgrade, Sremska Mitrovica and Pančevo by rail. The benefits of a short-range dry port are the relief for a seaport as well as relieving transport through the urban area. There are no such dry ports in the region of Western Balkans. There is no significant port in Europe that is not connected to its hinterland, either by rail or inland waterways with dry ports. As far as the port of Bar is concerned, there was only
$0.9 \%$ of transported containers by rail out of the total amount of 50,444 TEU (twenty-foot equivalent unit) (Port of Adria, 2019). The main competitor of the Bar port, the Port of Rijeka, transported $36 \%$ of transshipped containers by rail (AGCT, 2019a) while over $60 \%$ of containers were transported to and from Serbia by rail in 2019, according to the interviews with the main Serbian freight forwarders. As for the Port of Koper, out of all types of goods that were transshipped in the port, $2 / 3$ were transported by rail, i.e. every day there were about 64 trains from the port of Koper out of which 24 were container trains. The ratio of rail vs. truck intermodal transport was $38 \%$ vs. $62 \%$ in Rijeka while at the port of Koper this ratio was $52 \%$ vs. $48 \%$ in favor of rail container transport (Port of Koper, 2020).

\subsection{The Connection of the Port of Bar and the Port of Rijeka with its Hinterland}

In the year of 2019, the port of Bar (the operator of container terminal is Port of Adria) transshipped TEU 48.193, out of which 33.945 TEU were full containers (Port of Adria Bar, 2019). In the import 
of full containers, through the Port of Bar, the Montenegrin market participated with $30 \%$, the Serbian market with $60 \%$ while the remaining of $10 \%$ went to the markets of Bosnia and Herzegovina, Kosovo*, North Macedonia and the Northern part of Albania. As for export, the dependence of the Port of Bar on the regional cargo is even more noticeable, namely only $10 \%$ of full containers came from Montenegro, 55\% from
Serbia, 25\% from Bosnia and Herzegovina while the remaining $10 \%$ was the cargo from Kosovo*. The Montenegrin market had TEU 6.800, Serbia TEU 19.400 while Bosnia and Herzegovina, Kosovo*, Albania and North Macedonia had TEU 7.745 via Bar port. The data has been collected from (Customs Administration of Montenegro, 2020) and interviews with represents of shipping lines that operate in Bar port.

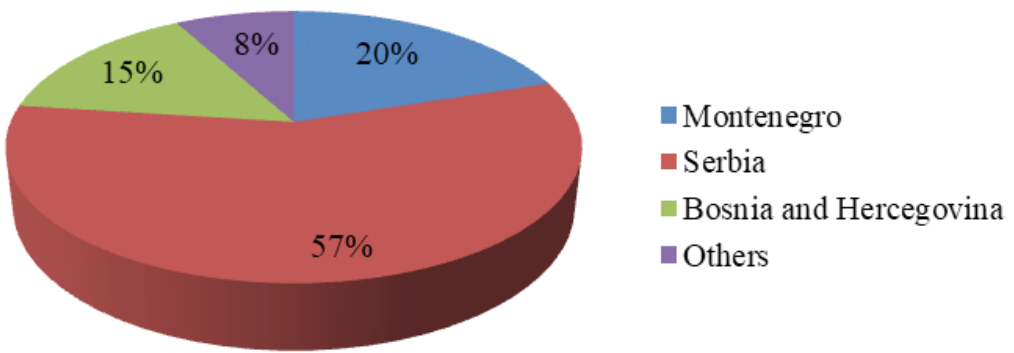

Fig. 2.

The Hinterland of Bar Port Shared by Cargo throughout in Import and Export Combined in 2019 Source: Author

Fig. 2 shows the Serbian market as the main hinterland of the port of Bar despite the fact Serbia serves around $70 \%$ of its intermodal needs through the port of Rijeka. The poor infrastructural connection of Bar port with the main economic centers in Serbia also calls into question the current amount of goods going through the Port of Bar which in the worst case scenario can bring into question the regular weekly feeder services at the Port of Bar. The port of Rijeka performed transshipment of TEU 271.378 in 2019, TEU
205.603 was full containers. This cargo is distributed by countries as follows Croatia - 34\%, Serbia-35\%, Bosnia and Herzegovina $-12 \%$, Hungary-12\%, Austria - 3\%, Czech Republic / Slovakia / Slovenia - 4\%. The main potential hinterlands of the port of Bar, which today mainly use the port of Rijeka, are Serbia with TEU 71.700 and Bosnia and Herzegovina with TEU 24.500 (AGCT, 2019b). The hinterland of the Port of Rijeka, shared by countries of import and export cargo for 2019 is given in Fig. 3.

\footnotetext{
* This designation is without prejudice to positions on status, and is in line with UNSCR 1244 and the ICJ Opinion on the Kosovo declaration of independence.
} 


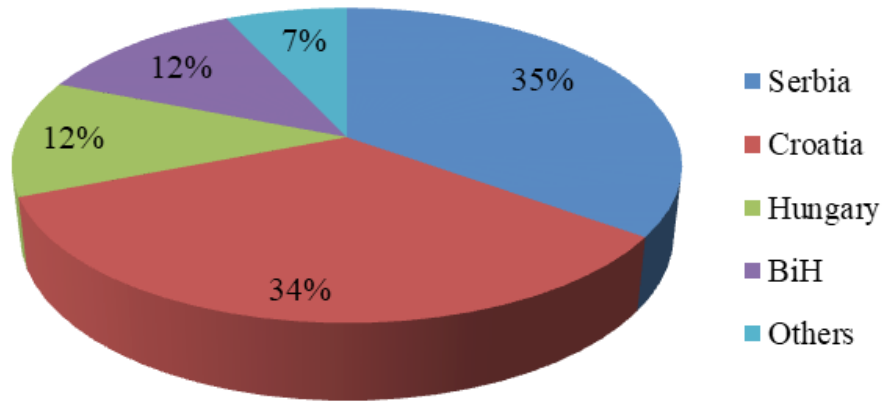

Fig. 3.

The Hinterland of Rijeka Port shared by Cargo throughout in Import and Export Combined in 2019 Source: Author

Screenings show the main hinterland of the Port of Bar, Serbia and Bosnia and Herzegovina together had around TEU 150.000 in 2019. Serbia had around TEU 110.000 while Bosnia and Herzegovina had TEU 40.000 of total its cargo to/from all regional ports. The both countries transported around $1 / 5$ of their total cargo through the Port of Bar, which means that the potential of the Port of Bar is far greater. The data collected in interviews arranged with represents of shipping lines and freight forwarders from region of Western Balkans. Although it has been trying for years to expand its hinterland to Central European countries, Serbia remains the main market for the port of Rijeka. In addition to the practical approach to operational problems on the site and the modernization of infrastructure and superstructure between Rijeka and Serbia, the poor infrastructural connection of the port of Bar with Serbia and Bosnia and Herzegovina helped to Rijeka additionally to get its good competitive position. Since the topic of this paper is rail intermodal transport, the next chapter will put focus on the Serbian market as a hinterland with which the port of Bar is connected by railway. The launch of regular container trains would allow to the logistic chain via Bar port to enjoy benefits of economy of scale what will be presented in the next chapters.

\subsection{Serbia as the Main Hinterland of the Port of Bar in Intermodal Transport}

The Serbian market is a fast growing and economically largest market in the Western Balkans, which was connected with two regional ports by the regular container railway traffic until 01/2020, the port of Rijeka and the port of Piraeus. As from $2 / 2020$, container train from Bar port was launched whose effects can be seen only in the next few years. This paper focuses on the period until $01 / 2020$ to better understand what could be one of the guidelines for the port of Bar in better positioning on the Serbian market and thus the greater container turnover via Bar port. The rail connection of the Serbian market with the regional sea ports is shown in fig. 4 . 


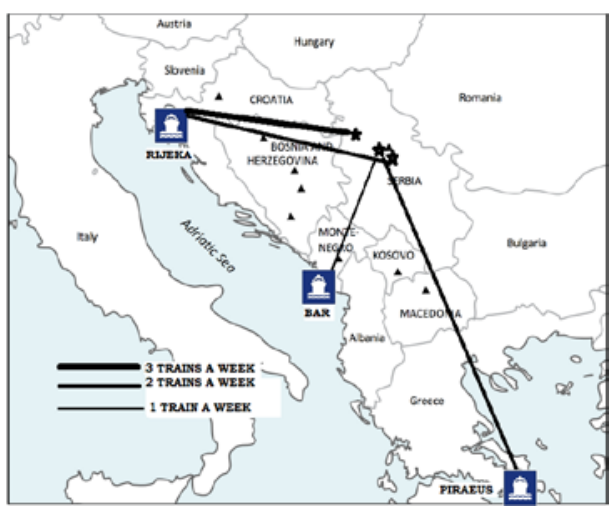

Fig. 4.

Connection of Existing Dry Ports in Serbia, in Sremska Mitrovica and Belgrade, with Regional Sea Ports in 3/2020

Source: Author

The marked region in Fig. 5 represents the area of around $70 \%$ Serbia's activities in intermodal transport, according to interviews organized with the most important Serbian logistics companies. Until 01/2020, that region was connected with 6 container trains per week from the direction of the Port of Rijeka and 1-2 trains per week from the direction of Piraeus. The intermodal terminal (dry port) Leget in Sremska Mitrovica is connected to Rijeka by 3 container trains while the dry port ŽIT Belgrade is connected to Rijeka by 3 additional trains a week. The dry port of Nelt Belgrade is connected with the Greek port of Piraeus with 1-2 trains per week and with the port of Bar with one train per week since $2 / 2020$. There was total of $35 \%$ of containers that were transshipped on the docks of the port of Rijeka and went to Serbia or came full from Serbia (AGCT, 2019b), while over $60 \%$ used the rail container transport, the remaining part used the truck transport according to the interviews with the main Serbian freight forwarders. The market of Serbia in intermodal transport is oriented towards Rijeka $70 \%$, Bar $17 \%$, while the port of Piraeus is used for $8 \%$ of the Serbian cargo, the ports of Thessaloniki, Burgas, Durres and Koper are represented with the remaining 5\%, according to interviews organized with the most important Serbian logistics companies. Although until last year, there were no container trains connecting Bar with the Serbian market. One circumstance helped the port of Bar to maintain such a significant volume of transshipment of Serbian cargo. There is a significant foreign trade imbalance between Serbia and Montenegro. Montenegro's foreign trade deficit with Serbia amounted to EUR 314 million in 2019 (Monstat, 2020) which led to a lot of conventional trucks with tarpaulins from Serbia coming to Montenegro, where they unload cargo. In order to avoid returning to Serbia empty trucks, they go to the port of Bar and for a relatively small amount of money agree to perform a transport. Out of the total cargo that comes to the port of Bar for the Serbian market, $70 \%$ is being stripped in the port to trucks, while the remaining $30 \%$ use trucks 
with container trailers, i.e. a container with goods is being loaded on a truck, according to interviews with logistics companies in Bar port. This has a negative impact on the further use of the port of Bar in the export of goods from Serbia, because of empty containers are located in the port itself. It would be far more useful if these containers came to Serbia from where they would be used for export.

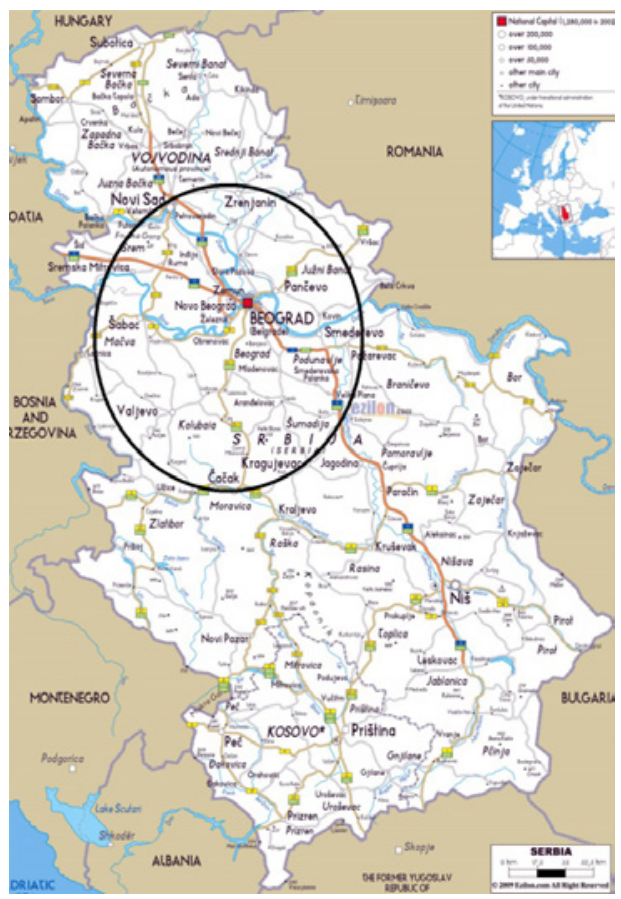

Fig. 5.

Marked Map of the Region in which up to 70\% of Intermodal Activities are Performed on the Serbian Market Source: Author

Notes: *This designation is without prejudice to positions on status, and is in line with UNSCR 1244 and the ICJ Opinion on the Kosovo Declaration of Independence

\section{Railway Intermodal Transport in the} Function of Better Competitive Position of the Port of Bar for the Serbian Market

The use of the principle of economies of scale is one of the main prerequisites for better positioning of a seaport in intermodal transport. In the next part of the paper, are analyzed and compared the cost prices, when loading a container in the port of
Bar and deliver it to the main economic centers in Serbia. It has been compared to the possibility of connecting the port of Bar with regular container trains to Belgrade and Niš in whose diameters of around $80 \mathrm{~km}$ is up to $90 \%$ of the Serbian cargo. The most important economic centers, where most intermodal activities in Serbia come from, are: Belgrade, Novi Sad, Niš, Kragujevac, Leskovac, Subotica, Kruševac, Kraljevo, 
Zrenjanin and Šabac. None of these cities is mostly connected to the port of Bar, while the cities in Vojvodina practically do not use the port of Bar but around 95\% link their business to the port of Rijeka. In the part that follows, it has been compared the current costs that exist for the transport of containers from the port of Bar to the mentioned centers, in accordance with the price lists of logistics services according to which logistics operations are performed today through the port of Bar. The port of Rijeka takes over about $3 / 4$ of the targeted cargo for the port of Bar, the cargo from
Serbia and Bosnia and Herzegovina. This paper excluded the analysis of the market of Bosnia and Herzegovina, as there is no railway connection between Bar port and this market. However, it still come to the fact that if today's amount of Serbian cargo throughput only (all other possibilities in the sense of other regional cargos, are not considered) could be directed to Bar, the port of Bar would get three times more container throughput than it has today. Table 1 gives the structure of container transport costs since the ship's arrival in the port of Bar. This data were collected on the site in Bar.

\section{Table 1}

Cost Structure in Intermodal Land Transport through the Port of Bar

\begin{tabular}{|c|c|c|}
\hline Type of Cost & Inland Transportation Case & Railway Transportation Case \\
\hline $\begin{array}{c}\text { Agency cost of Shipping Lines } \\
\text { Loading+Discharging of } \\
\text { Container on/from Transport } \\
\text { Vehicle }\end{array}$ & $\begin{array}{c}\text { The same costs amount in the case } \\
\text { transportation }\end{array}$ & $\begin{array}{c}\text { The same costs amount in the case } \\
\text { of inland transportation and railway } \\
\text { transportation }\end{array}$ \\
\hline $\begin{array}{c}\text { Cleaning of Container } \\
\text { the }\end{array}$ & $\begin{array}{c}\text { The same costs amount in the case } \\
\text { of inland transportation and railway } \\
\text { transportation }\end{array}$ & $\begin{array}{c}\text { The same costs amount in the case } \\
\text { of inland transportation and railway } \\
\text { transportation }\end{array}$ \\
\hline Customs Brokerage Fee & $40 €$ & $30 €$ 15 $€$ \\
\hline Price of Transportation & Depend on destination & Depend on destination \\
\hline
\end{tabular}

Source: Author

In the table 1 is noted that the shipping locally agency costs not depend on the type of land intermodal transportation mode and will not be further analyzed. As for the remaining port costs, loading or unloading of a full container as well as the customs brokerage fee when using the railway, are lower by $255 \%$ or 70 EUR per container. As for the price of road transport in intermodal transport, it will be based on the commercial offer of truckers as well as the railway operator that started with the service as from $02 / 2020$ on the route Bar - Belgrade - Bar. Although there is no container train on the route Bar - Niš- Bar nor an intermodal terminal that is currently under construction, it is assumed it exists in accordance with the commercial offer on the 
route Bar - Niš - Bar provided by railways operators Serbiacargo and Montecargo. In table 2, the prices of truck transportation on the subject routes are stated. In order to fully review the current situation in intermodal truck transportation via the port of Bar, it should be noted that it is at a lower level of development compared to Rijeka because there are not enough export jobs that would allow truckers to work in both directions. Namely, truckers offer one-way prices with the obligation to return empty container to Bar. However, the price of an empty-full container is not profitable for any trucker and in order to function somehow, the truckers load cargo back to Montenegro in containers. That cargo will not be loaded on the ship, but will be unloaded on the territory of Montenegro and a container be returned empty to the port. This is not allowed by the shipping lines, but there is no possibility of controlling and it passes. This enabled the reduction of the prices of empty-full container transport by about $15 \%$, i.e. about $200 €$ so there are the following prices expressed in the table 2 .

Table 2

Prices of Truck Intermodal Transport in Import

\begin{tabular}{|c|c|c|}
\hline $\begin{array}{c}\text { Place of picking up Full } \\
\text { Container and Bringing Back } \\
\text { Empty }\end{array}$ & Final Destination & Price in EUR \\
\hline Port of Bar & Belgrade & $650 €$ \\
\hline Port of Bar & Novi Sad & $730 €$ \\
\hline Port of Bar & Niš & $730 €$ \\
\hline Port of Bar & Kragujevac & $650 €$ \\
\hline Port of Bar & Leskovac & $750 €$ \\
\hline Port of Bar & Subotica & $850 €$ \\
\hline Port of Bar & Kruševac & $650 €$ \\
\hline Port of Bar & Kraljevo & $620 €$ \\
\hline Port of Bar & Zrenjanin & $730 €$ \\
\hline Port of Bar & Šabac & $730 €$ \\
\hline
\end{tabular}

Source: Author

In table 3 the prices related to export flows are presented, i.e. if it is necessary to export cargo in container from Serbia via the port of Bar. All above data has been collected by truckers from Montenegro that performs intermodal truck activities connecting Bar port and Serbia. In a small number of cases it is possible to pair import operations with export ones, when containers after being unloaded at import places being sent for loading at export places. Although such situations occur, they are not sure that logistics companies would base their commercial offers to customers (as do when perform export via Rijeka) but base its commercial offers for end-users in the amounts listed in table 3.The case, when empty containers are being picked up at the port of Bar and shipped out for export loading of cargo. Logistics companies add their margin to these amounts, while if it happens to use the import container 
for export, they keep an extra earning for themselves while paying the truckers up to $50 \%$ less than to haul an empty container from Bar. As end customers who pay for logistics services determine where the goods will go, to Bar or Rijeka, and while logistics companies do not want to take the risk and offer export business through Bar on a oneway basis, this paper considered the prices they really pay given in Table 3 .

Table 3

Prices of Truck Intermodal Transport in Export

\begin{tabular}{|c|c|c|}
\hline $\begin{array}{c}\text { Place of Picking up Empty } \\
\text { Container and Bringing Back Full }\end{array}$ & Place of Receipt & Price in EUR \\
\hline Port of Bar & Belgrade & $750 €$ \\
\hline Port of Bar & Novi Sad & $850 €$ \\
\hline Port of Bar & Niš & $850 €$ \\
\hline Port of Bar & Kragujevac & $750 €$ \\
\hline Port of Bar & Leskovac & $900 €$ \\
\hline Port of Bar & Subotica & $950 €$ \\
\hline Port of Bar & Kruševac & $780 €$ \\
\hline Port of Bar & Kraljevo & $730 €$ \\
\hline Port of Bar & Zrenjanin & $850 €$ \\
\hline Port of Bar & Šabac & $880 €$ \\
\hline
\end{tabular}

Source: Author

It is compared the above conditions and prices from tables 1,2 and 3 with the prices in the case of using rail intermodal container transportation on the route Bar - Belgrade - Bar or Bar - Niš - Bar. It is assumed that there is already an intermodal terminal in Niš and established regular container line Bar - Niš - Bar (planned for 2021). It should be noted that each container in the import is returned empty to the intermodal terminal (dry port) in Belgrade or Niš, although in practice there is a possibility it would be used for an export business. However, similar to truck transport through the port of Bar, when logistics companies at the time of bidding to the end user of the service do not take into account this possibility but offer the full price, likewise, logistics companies do not take into account the possibility of using the same container in export but calculate they will take over an empty one from dry port in Belgrade or Niš. Accordingly, we have the following cost structure in rail intermodal transportation, both for imports and exports, listed in Table 4. The advantage over the truck's intermodal route is the container train operator must offer prices based on 2 directions, i.e. it must decrease the price of transport in order to attract enough cargo, calculating that it will employ the train in both directions; otherwise it would not be profitable. This does not allow the train operator an extra profit as in the case of truck transport but animates users and the benefits are reflected in the lower cost of transport for the end users. Furthermore, the train operator makes a profit on the amount of transported containers. 


\section{Table 4}

Prices of Rail Intermodal Transportation on the Route Bar-Belgrade and Bar-Niš

\begin{tabular}{|c|c|}
\hline $\begin{array}{c}\text { Type Cost on the Rail Intermodal Route } \\
\text { Bar-Belgrade-Bar }\end{array}$ & Price in EUR \\
\hline Transportation of 20dv/40" in import Bar-Belgrade & $175 / 240$ \\
\hline Transportation 20dv/40 in export Belgrade-Bar & $145 / 205$ \\
\hline $\begin{array}{c}\text { Summary declaration } \\
\text { (Customs brokerage costs at dry port) }\end{array}$ & 15 \\
\hline Lift on/lift off on dry port & Table 5 \\
\hline Last mile truck transportation & Price in EUR \\
\hline $\begin{array}{c}\text { Bype Cost on the Rail Intermodal Route } \\
\text { Bar-Bar }\end{array}$ & $205 / 270$ \\
\hline Transportation of 20dv/40" in import Bar-Niš & $175 / 235$ \\
\hline Transportation 20dv/40 in export Niš-Bar & 15 \\
\hline $\begin{array}{c}\text { Summary declaration } \\
\text { (Customs brokerage costs at dry port) }\end{array}$ & 80 \\
\hline Lift on/lift off on dry port & Table 6 \\
\hline Last mile truck transportation & \\
\hline
\end{tabular}

Source: Author

There are the two main limitations that prevent lower prices of transport per intermodal unit on these routes. Max. carrying capacity of the railway is 1,060 tons, while from Rijeka to Serbia the max. gross permissible train capacity is 1,600 tons, or even $50 \%$ more. While it is possible to load 3 TEU full containers on one wagon via Rijeka, it is possible to load only 2 TEU full containers via $B$ ar, which reduces competitiveness by $33 \%$. The lack of wagons and the unsuitability of certain rules when passing a $40 \mathrm{HC}$ container through certain tunnels, limits the additional reduction of prices on the logistics route through the Port of Bar and thus greater competitiveness of the route. The last mile costs are given in Table 5. The data from table 4 and 5 are collected based on commercial offers of railway operators (Montecargo AD, 2019) and (Serbiacargo AD, 2019) respecting limitations on the present routes to Belgrade and Niš from Bar.

\section{Table 5}

Last Mile Costs of Intermodal Transport from Dry Ports to Designated Economic Centers

\begin{tabular}{|c|c|c|}
\hline Dry Port & $\begin{array}{c}\text { Final Destination/ } \\
\text { Place of Receipt }\end{array}$ & Price in EUR \\
\hline Belgrade & Belgrade & 150 \\
\hline Belgrade & Kragujevac & 320 \\
\hline Belgrade & Subotica & 400 \\
\hline Niš & Kraljevo & 350 \\
\hline Belgrade & Zrenjanin & 250 \\
\hline Belgrade & Novi Sad & 220 \\
\hline Belgrade & Šabac & 260 \\
\hline Niš & Niš & 120 \\
\hline Niš & Kruševac & 220 \\
\hline Niš & Leskovac & 180 \\
\hline
\end{tabular}

Source: Author 
After all data given in the previous tables and limitations explained, a comparative analysis of truck and rail intermodal transportation is depicted in Figure 5. In the case of truck transport there is the same price for transport of $20 \mathrm{dv}, 40 \mathrm{dv}$ or $40 \mathrm{HC}$ containers, while in the case of intermodal rail transportation the price differs for $20 \mathrm{dv}$ and $40 \mathrm{dv} / \mathrm{HC}$. Summarized associated costs, described in Tables 1-5, are presented in Fig.5.



Fig. 6.

Comparative Analysis of Transport Prices with Accompanying Costs in Import Operations on the Route Bar - the Main Economic Centers in Serbia

Source: Author

Accordring to Fig.6, by regularly offering prices to end users in Serbia, the port of Bar would be significantly more competitive than the case is today. This is especially noticeable for cities in Vojvodina, as well as for Belgrade and Niš, where the main economic activities in Western Balkans area take place. The difference for the cities in the central part of Serbia is less pronounced from the two reasons, the proximity of Bar for trucks and the distances from intermodal terminals (dry ports) in Belgrade and Niš. The use of rail intermodal transport compared to the current use of truck container transport reduces the price by an average of $226 €$ / container or $27 \%$ for import inland operations. As far as exports are concerned, the difference is even more noticeable. The overview is given in Fig.7. 


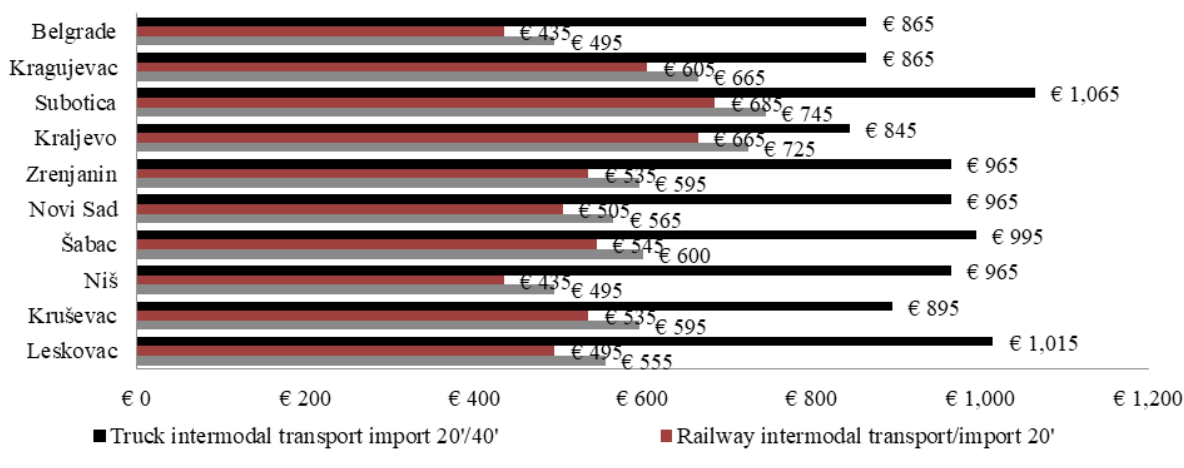

- Railway intermodal transport/import $40^{\prime}$

Fig. 7.

Comparative Analysis of Transport Prices with Accompanying Costs in Export Operations on the Route, the Main Economic Centers in Serbia-Bar

Source: Author

The launching of rail intermodal transport in the offer of logistics companies for the export of containers through the port of Bar, from the observed economic centers would lead to an average reduction in transport prices of $370 €$ per container, or $39 \%$ compared to today's set up.

\section{Conclusion and Recommendation}

One of the main reasons for the non competitiveness of the logistics intermodal route through the port of Bar can be seen in the fact that the rail intermodal transport was used only in $0.9 \%$ of the arrived containers in the port of Bar in 2019, while through the port of Rijeka for the Serbian market it was over $60 \%$. In the case of the port of Bar, there are several challenges to be faced. These challenges are best evidenced by the logistics route via Rijeka port when on the beginning of 21 th century; they were struggling to establish a regular container train with Serbia. At the end of 2019, Rijeka had 6 container trains a week that connect the port of Rijeka and the Serbian market. They were expected to reach more than 10 container trains a week at the end of 2021.

In the meantime, a lot has been done on the reconstruction of the railway between the port of Rijeka and Belgrade, which has increased the maximum capacity of the train by $50 \%$. The purchase of specialized wagons for the transport of containers has additionally reduced the price of intermodal transport per transport unit. As result, the most important hinterland of the port of Rijeka is Serbia with $35 \%$ of the total cargo transshipment, while Serbia itself uses the port of Rijeka for around $70 \%$ of its goods. That percentage would be a higher if there were no a lot of empty trucks that, due to the foreign trade deficit of Montenegro with Serbia, go to the port of Bar to pick up goods from containers at low prices.

The port of Bar has a railway connection with Serbia. It should be noted that the distance 
from the port of Rijeka to Belgrade is 661 $\mathrm{km}$, while the distance from Bar to Belgrade is $476 \mathrm{~km}$, i.e. $30 \%$ shorter and the railway passes through Serbia for a much larger part than when Serbia uses the port of Rijeka for its needs. This fact should positively affect Serbia's interest in redirecting more of its goods to the port of Bar. The basic precondition for greater valorization of the port of Bar is the completion of the reconstruction of the railway Bar - Belgrade, which has already been reconstructed in the length of about $30 \%$. The purchase of specialized wagons by railway operators, after the reconstruction of the railway, should be a priority. However, even under these circumstances, if the Bar port starts with a more serious promotion of intermodal rail transportation on the Serbian market, there would be greater transshipment of containers at the docks of the port of Bar itself because of the import price would be lower by $27 \%$ and exports by $39 \%$ per container.

Logistics companies from Serbia are not sufficiently motivated to use rail intermodal connection with Bar. Therefore, Montenegrin logistics companies and the State of Montenegro should encourage it because it is the basic precondition for far more intensive logistics operations through the port of Bar, which should result in the introduction of regular shipping lines from Asia and further lower prices for logistics services through the port of Bar. It would lead a higher share of logistics activities to the GDP of Montenegro.

\section{References}

AGCT. 2019a. The most cost effective Adriatic GATEWAY. Official Presentation. AGCT Rijeka, Croatia. 18p.
AGCT. 2019b. Annual statistics. AGCT Rijeka, Croatia. Available from Internet: $<$ https://www.portauthority. hr/en/traffic-statistics/>.

Bask, A.; Roso, V.; Andersson, D.; Hamalainen, E. 2014. Development of seaport-dry ports dyads: two cases from Northern Europe, Journal of Transport Geography 39: $85-95$.

COSCO Shipping Greece. 2020. Rail transportation. Available from Internet: <https://www.coscoshipping. gr/rail/\#>.

Customs Administration of Montenegro. 2020. The report of cross border passing in cargo transport, Podgorica, Montenegro. 3p.

European Commission. 2011. White Paper on Roadmap to a Single European Transport Area - Towards a competitive and resource efficient transport system. Brussels, 30p.

Mlinarić, T.J.; Rogić, K.; Rožić, T. 2011. Methodology for determining dry port system transport networkCase study port of Rijeka-Zagreb, DAAAM International Scientific Book 10: 133-146.

Naletina, D.; Perkov, E. 2017. The economic importance of maritime shipping with special reference on Croatia. In Proceedings of the $19^{\text {th }}$ International Scientific Conference on Economic and Social Development, Melbourne, Australia, 248-257.

Montecargo AD. 2019. Commercial offer for container transportation, Podgorica, Montenegro.

Monstat. 2020. Statistical office of Montenegro. Available from Internet: <https://www.monstat.org/ eng/index.php >.

Port of Adria. 2019. Container Statistics by Lines. Port of Adria, Bar. Available from Internet: <https:// data.worldbank.org/indicator/IS.SHP.GOOD. $\mathrm{TU}$ ?locations $=\mathrm{ME}>$. 
Port of Antwerp. 2020. Cargo transport. Available from Internet: <https://www.portofantwerp.com/en/ cargo-transport $>$.

Port of Hamburg. 2020. Statistics. Available from Internet: <https://www.hafen-hamburg.de/en/statistics $>$.

Port of Koper. 2020. Port connection. Available from Internet: <https://www.luka-kp.si/eng/railwayconnections $>$.

Rodrigue, J.P.; Notteboom, T. 2009. The geography of containerization: half a century of revolution, adaptation and diffusion, GeoJournal 74(1): 1-5.

Roso, V.; Woxenius, J.; Lumsden, K. 2009. The dry port concept: connecting container seaports with the hinterland, Journal of Transport Geography 17(5): 338-345.

Roso, V. 2013. Sustainable intermodal transport via dry ports - importance of directional development, World Review of Intermodal Transportation Research 4(23):140-156.
Serbiacargo AD. 2019. Commercial offer for container transportation, Belgrade, Serbia.

Unctad. 2019. Review of maritime transport. Available from Internet: <https://unctad.org/system/files/ official-document/rmt2019_en.pdf $>$.

UnctadSTAT. 2020. Port liner shipping connectivity index. Available from Internet: <https:// unctadstat.unctad.org/wds/TableViewer/tableView. aspx?ReportId $=170026>$.

Woxenius, J.; Bergqvist, R. 2008. Hinterland transport by rail-a success for maritime containers but still a challenge for semi-trailers. In 13th Annual Logistics Research Network Conference, University of Liverpool, 10-12.

\section{jitte 374}

